\title{
PENGARUH PEMBERIAN EKSTRAK ETANOL 70\% DAUN MATOA (Pometia pinnata) TERHADAP KADAR SUPEROXIDE DISMUTASE (SOD) HATI TIKUS
}

\author{
Devi Maulina \\ Maulinadevi2011@gmail.com, Politeknik Kesehatan Hermina
}

\begin{abstract}
Matoa leaves (Pometia pinnata) contain flavonoids which predictedly has antioxidant activity. This study aims to examine the antioxidant activity to 70\%-ethanol of Matoa leaves extract on rat (Sprague Dawley) liver induced by $\mathrm{CCl}_{4}$. This study uses a completely random design with 30 rats divided into 6 groups. Normal groups; Negatif Control, Positif Control were given curcuma $81 \mathrm{mg} / \mathrm{kg}$ for 10 days; Extract Group were given 70\%-ethanol extract Matoa leaves (Pometia pinnata) with various dosages consecutively of $100 \mathrm{mg} / \mathrm{kg} \mathrm{BW,} 200 \mathrm{mg} / \mathrm{kg} \mathrm{BW,} \mathrm{and} 400 \mathrm{mg} / \mathrm{kg} \mathrm{BW}$ during 10 days. All groups instead of Normal Control were induced by CCl 0,05 cc/day during 5 days. On day 16th, liver of rats were checked for examining the levels of superoxide dismutase (SOD). SOD level in normal group was

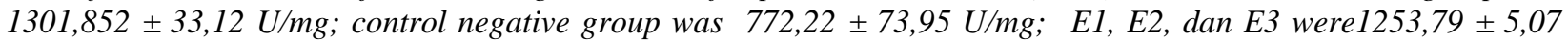
$\mathrm{U} / \mathrm{mg} ; 1411,11 \pm 64,68 \mathrm{U} / \mathrm{mg}$ and 1376,57 $\pm 12,06 \mathrm{U} / \mathrm{mg}$. Statistics analysis using One Way ANOVA showed significant difference between extract treatment groups and negatif control group. It can be concluded that the $70 \%$-ethanol of Matoa leaves extract can increase SOD levels in liver.

Keyword : Antioxidant, SOD liver, Matoa leaves (Pometia pinnata)
\end{abstract}

\begin{abstract}
Abstrak
Daun matoa (Pometia pinnata) mengandung senyawa flavonoid yang diduga mempunyai aktivitas sebagai antioksidan. Penelitian ini bertujuan untuk menguji pengaruh ekstrak etanol 70\% daun matoa terhadap kadar SOD pada hati tikus putih jantan galur Sprague dawley yang diinduksi $\mathrm{CCl}_{4}$. Penelitian ini menggunakan rancangan acak lengkap dengan 30 ekor tikus yang dibagi dalam 6 kelompok. Kelompok normal, kontrol negatif, kontrol positif diberi curcuma 81 $\mathrm{mg} / \mathrm{kg}$ BB selama 10 hari; dan Kelompok Ekstrak Etanol 70\% daun matoa dengan variasi dosis 100 mg/kg BB, 200 $\mathrm{mg} / \mathrm{kg} \mathrm{BB}$, dan $400 \mathrm{mg} / \mathrm{kg}$ BB selama 10 hari. Semua kelompok kecuali kelompok normal di induksi dengan $\mathrm{CCl}_{4}$ dosis $0,05 \mathrm{cc} /$ hari selama 5 hari. Pada hari ke-16, dilakukan pengambilan organ hati kemudian dilakukan pemeriksaan kadar Superoksida Dismutase (SOD). Pemeriksaan kadar SOD yang diperoleh dari kelompok normal adalah 1301,852 $\pm 33,12 \mathrm{U} / \mathrm{mg}$, sedangkan pada kontrol negatif kadar SOD lebih rendah yaitu 772,22 $\pm 73,95 \mathrm{U} / \mathrm{mg}$. Kadar SOD pada E1, E2, dan E3 berturut-turut yaitu 1253,79 $\pm 5,07 \mathrm{U} / \mathrm{mg} ; 1411,11 \pm 64,68 \mathrm{U} / \mathrm{mg}$ dan 1376,57 $\pm 12,06 \mathrm{U} / \mathrm{mg}$. Analisis statistik menggunakan one way anova menunjukan kadar SOD berbeda bermakna pada setiap kelompok ekstrak dibanding dengan kelompok kontrol negatif. Dapat disimpulkan bahwa ekstrak etanol 70\% daun Matoa dapat meningkatkan kadar SOD hati.
\end{abstract}

Kata kunci : $\quad$ Antioksidan, Daun matoa (Pometia pinnata), SOD hati.

\section{PENDAHULUAN}

Proses metabolisme tubuh menyebabkan sel menghasilkan radikal bebas dan kelompok oksigen reaktif (Reactive Oxygen Species/ROS). Pada saat produksi radikal bebas melebihi antioksidan pertahanan seluler maka dapat terjadi stres oksidatif (Sinaga, 2016). Secara alami antioksidan dapat diproduksi didalam sel tubuh sebagai pertahanan bagi organel-organel sel dari pengaruh kerusakan akibat reaksi radikal bebas. Namun saat terjadi stres oksidatif tubuh memerlukan asupan antioksidan dari luar agar kerusakan jaringan akibat stres oksidatif dapat dihindari (Werdhasari, 2014).

Matoa (Pometia pinnata) merupakan tanaman khas Papua termasuk famili Sapindaceae yang belum dimanfaatkan secara maksimal sebagai tanaman obat. Dari penelitian in vitro dengan metode DPPH diketahui ekstrak etanol daun matoa memiliki aktivitas antioksidan (Martiningsih et 


\section{Indonesian Journal of Health Science}

Volume 1 No. 1, Juni 2021

al., 2016). Namun secara in vivo belum diketahui aktivitas antioksidan ekstrak daun matoa terhadap kadar SOD di hati.

Penelitian ini dilakukan untuk menilai aktivitas antioksidan ekstrak daun Matoa (Pometia pinnata) secara in vivo dengan mengukur kadar SOD pada hati tikus putih jantan yang diinduksi dengan karbon tetraklorida $\left(\mathrm{CCl}_{4}\right)$. Karbon tetraklorida $\left(\mathrm{CCl}_{4}\right)$ adalah salah satu bahan yang dapat menimbulkan stress oksidatif pada hepar oleh karena di dalam retikulum endoplasmik sel hepar dapat dirubah menjadi radikal bebas $\mathrm{CCl}_{3}$ (Werdhasari et al., 2016). Dari hasil penelitian ini diharapkan menjadi informasi yang berguna dalam melengkapi fitofarmaka Indonesia.

\section{METODE}

Penelitian dilakukan secara eksperimental menggunakan rancangan acak lengkap dengan 30 ekor tikus yang dibagi dalam 6 kelompok. Kelompok normal, kontrol negatif, kontrol positif diberi curcuma $81 \mathrm{mg} / \mathrm{kg}$ BB selama 10 hari; dan kelompok ekstrak etanol 70\% daun matoa (E1, E2, dan E3) dengan variasi dosis $100 \mathrm{mg} / \mathrm{kg} \mathrm{BB}, 200 \mathrm{mg} / \mathrm{kg} \mathrm{BB}$, dan $400 \mathrm{mg} / \mathrm{kg}$ BB selama 10 hari. Semua kelompok kecuali kelompok normal di induksi dengan $\mathrm{CCl}_{4}$ dosis $0,05 \mathrm{cc} /$ hari selama 5 hari. Pada hari ke-16, dilakukan pengambilan organ hati kemudian dilakukan pemeriksaan kadar Superoksida Dismutase (SOD) menggunakan spektrofotometer dengan prosedur sesuai penelitian (Jewett et al., 1993) sebagai berikut. Sebanyak $10 \mu$ homogenat hati dari tiap-tiap kelompok perlakuan ditambahkan dengan $2750 \mu \mathrm{l}$ buffer karbonat 0,0578 M pH 10,2, $90 \mu \mathrm{l}$ air dan $150 \mu$ l epinefrin 0,01 M kemudian divortex hingga homogen. Selanjutnya dikocok kembali hingga homogen dan dibaca absorbannya pada panjang gelombang $480 \mathrm{~nm}$ pada suhu $30^{\circ} \mathrm{C}$, setelah menit ke 1 dan 3 . Sebagai blanko dimasukkan $2800 \mu \mathrm{l}$ buffer karbonat, $100 \mu \mathrm{l}$ aquadest dan $100 \mu 1$ epinefrin.

\section{HASIL DAN PEMBAHASAN}

Karbon tetraklorida $\left(\mathrm{CCl}_{4}\right)$ digunakan sebagai penginduksi pada kelompok kontrol negatif karena Karbon tetraklorida $\left(\mathrm{CCl}_{4}\right)$ relatif mudah didapat, harganya terjangkau dan dalam dosis kecil dapat menimbulkan kerusakan hati pada hewan percobaan. Selain itu karbon tetraklorida $\left(\mathrm{CCl}_{4}\right)$ dapat diubah oleh sitokrom $\mathrm{P} 450$ menjadi metabolit reaktif yaitu triklorometil peroksi yang dapat menyebabkan peroksidasi lipid sehingga mengakibatkan kerusakan pada sel-sel hati dan juga sel-sel tubuh lainnya. Superoksida Dismutase (SOD) merupakan antioksidan endogen yang berfungsi sebagai pertahanan terhadap stress oksidatif, sehingga peningkatan stress oksidatif akan menurunkan kadar antioksidan tersebut (Werdhasari et al., 2016).

Tabel 1. Kadar SOD Hati

\begin{tabular}{cc}
\hline Kelompok & Kadar SOD (U/mg) \\
\hline Normal & $1301,852 \pm 33,12 \mathrm{U} / \mathrm{mg}$ \\
\hline Kontrol Negatif & $772,22 \pm 73,95 \mathrm{U} / \mathrm{mg}$ \\
\hline Kontrol Positif & $955,55 \pm 33,12 \mathrm{U} / \mathrm{mg}$ \\
\hline E1 & $1253,79 \pm 5,07 \mathrm{U} / \mathrm{mg} *$ \\
\hline E2 & $1411,11 \pm 64,68 \mathrm{U} / \mathrm{mg}^{*}$ \\
\hline E3 & $1376,57 \pm 12,06 \mathrm{U} / \mathrm{mg}^{*}$ \\
\hline
\end{tabular}

Tanda * menunjukan perbedaan bermakna. 


\section{Indonesian Journal of Health Science}

Volume 1 No. 1, Juni 2021

Kadar SOD yang diperoleh dari kelompok normal adalah 1301,852 \pm 33,12 U/mg, sedangkan pada kontrol negatif aktivitas SOD lebih rendah yaitu 772,22 $\pm 73,95 \mathrm{U} / \mathrm{mg}$. Kadar SOD pada E1, E2, dan E3 berturut-turut yaitu 1253,79 \pm 5,07 U/mg; 1411,11 \pm 64,68 U/mg dan 1376,57 $\pm 12,06 \mathrm{U} / \mathrm{mg}$. Hasil analisa statistik ANOVA satu arah menunjukan adanya perbedaan yang bermakna aktivitas SOD pada kontrol negatif dengan E1, E2 dan E3 (p<0,05).

Rendahnya kadar SOD pada kontrol negatif diduga karena banyaknya radikal anion superoksida yang terbentuk, yang menimbulkan suatu keadaan stres oksidatif sehingga enzim SOD hati tidak mampu lagi untuk mengkatalisis radikal anion superoksida.

Pemberian ekstrak etanol daun matoa (pometia pinnata) dapat meningkatkan kadar SOD menunjukan bahwa adanya efek antioksidan yang disebabkan adanya kandungan zat aktif seperti flavonoid pada ekstrak etanol 70\% daun matoa (pometia pinnata)(Martiningsih et al., 2016). Senyawa flavonoid yang berfungsi sebagai antioksidan fenolik, yang dapat menghambat peroksidasi lipid melalui donasi atom $\mathrm{H}$ kepada radikal peroksil (ROO*) dan menghasilkan suatu bentuk alkil/aril hidroperoksida. Mekanismenya dapat digambarkan sebagai berikut: ROO* $+\mathrm{PPH}$ (Phenolic Antioxidant) $\rightarrow$ ROOH + PP* (Mahmud et al., 2021).

Radikal polifenol fenoksil (PP*) yang dihasilkan dari reaksi tersebut dapat distabilkan melalui donasi atom $\mathrm{H}$ dan membentuk suatu senyawa kuinolon, atau bereaksi dengan radikal lain,misalnya radikal polifenol fenoksil lain (Mahmud et al., 2021).

\section{PENUTUP}

Ekstrak etanol $70 \%$ daun matoa (pometia pinnata) dapat meningkatkan kadar SOD hati tikus Sprague dawley yang diinduksi $\mathrm{CCl}_{4}$.

\section{DAFTAR PUSTAKA}

Mahmud, N. R. A., Muhammad, N., \& Nurhalifah. (2021). Effect of the Adding of Natural Antioxidant in the Stored Traditional Coconut Oil on the Free Fatty Acid Value. Proc. Internat. Conf. Sci. Engin, 4(February), 76-79.

Martiningsih, N. W., Widana, G. A. B., \& Kristiyanti, P. L. P. (2016). Skrining fitokimia dan uji aktivitas antioksidan ekstrak etanol daun Matoa (Pometia pinnata) dengan metode DPPH. Prosiding Seminar Nasional MIPA, O(0), 332-338.

Sinaga, F. A. (2016). Stress oksidatif dan status antioksidan pada aktivitas fisik maksimal. Jurnal Generasi Kampus, 9(2), 176-189.

Werdhasari, A. (2014). Peran Antioksidan Bagi Kesehatan. Jurnal Biomedik Medisiana Indonesia, 3(2), 59-68.

Werdhasari, A., Prijanti, A. R., \& Jusman, S. W. A. (2016). Peran Sitoglobin dalam Mencegah Stres Oksidatif pada vertebrata . Ekspresi gen Cygb Metode eksperimental in vivo. Untuk mengetahui adalah dengan mereaksikan. April, 9-19. 